\title{
Assessment of savings and Asset allocation behaviour on low income individuals in Rural Kenya: Case of Oyani Sub Location, Kenya.
}

\author{
Benard Otieno Konya ${ }^{* 1}$, Simon Nyakwara ${ }^{* 2}$ \\ 1. Masters Degree in Public Administration and Management of Mount Kenya University. \\ 2. Doctor of Philosophy\& Director of Kisii Campus of Mount Kenya University.
}

\begin{abstract}
The goal of the government of Kenya as is spelled out in Vision 2030 is to stimulate the rate of annual growth to over $10 \%$ every year till the year 2030 , this kind of growth will enable the country to transform into a middleincome economy. Thus, the purpose of the study was to find out the factors that influence saving behaviours and asset allocation among low income households in rural areas Kenya: A case of Oyani Sub Location, Kenya. The objectives of the study were to: examine the relationship between financial literacy and saving behaviours and asset allocation decision in rural Kenya: A case of Oyani Sub Location, Kenya; identify the how financial institutions' characteristics influences saving behavior and asset allocation in rural Kenya: A case of Oyani Sub Location, Kenya; evaluate how fiscal policy influences saving and asset allocation in rural Kenya: A case of Oyani Sub Location, Kenya and establish if there is a relationship between household head's demographic information and saving and asset allocation in rural Kenya: A case of Oyani Sub Location, Kenya. The information that provided by this research will benefit policymakers, community members and academicians. It adopted $\mathrm{a}$ in the case study research design with a target population of 3569 households in the rural areas of Oyani. The sample size was 351 heads of the household. The researcher adopted stratified random sampling technique and collected data using questionnaires. The instruments were validated by the supervisors. Reliability of the instruments were determined through a pilot study where Cronbach alpha coefficients of 0.7 was considered appropriate. Quantitative data was analyzed using descriptive and inferential statistics, thereafter, presented in tables. The study revealed that financial literacy $(\mathrm{t}=4.277, \mathrm{P}<.05)$, financial institutions' characteristics $(\mathrm{t}=6.130, \mathrm{P}<.05)$, fiscal policy $(\mathrm{t}=2.854, \mathrm{P}<.05)$ and household's head's demographic information $(\mathrm{t}=7.489, \mathrm{P}<.05)$ significantly affect saving behaviours and asset allocation among low income households in rural areas Kenya: A case of Oyani Sub Location, Kenya. Besides, these results imply that household head's demographic information is most $(\mathrm{t}=7.489, \mathrm{P}<.05)$ important predictor for savings behaviour and asset allocation decision. The study recommends that the government and other financial service providers to focus more on the issue of saving and asset allocation decisions for low income households in rural areas. In particular, they should train low income households in rural areas.
\end{abstract}

Key Words: Savings and Asset allocation behaviour, Low income individuals in rural Kenya, Oyani Sub Location Kenya.

DOI: $10.7176 /$ PPAR/9-2-09

\subsection{Background Information}

Savings and asset allocation decision are of interest to both policymakers and scholars across many disciplines, because of their importance to individuals, households, and the economy. For individuals and households, economic security throughout the life course is inherently linked not only to income but also to asset ownership. Savings and assets are important because, unlike income, they are what individuals and families accumulate and hold over time. Assets, such as savings, also generate returns that generally increase for the economy at large, savings represents an important source for the financing of investment in developing countries. The savings rate of a country has been found to be strongly correlated with investment and growth rates (Attanasio \& Banks, 2001).

A sufficient supply of savings especially from domestic inhabitants is a core national policy of any government, this should be especially true of developing nations which need to achieve the development visions set out for example Kenyan's vision 2030. This is because research has shown that there exists a positive relationship between savings and economic growth (Alguacil et al 2004). A study by (Todaro and Smith, 2006) confirmed the hypothesis that higher savings usually precede economic growth.

One of the ways in which countries can stimulate long term economic growth is thorough mobilization of savings so as to fund enough investments (Mbuthia 2011). Investments can be financed through one of the two ways: either through domestic savings or in the form of foreign aid and foreign direct investments. Although Africa at large and Kenya in particular receive a lot in foreign aid the impact of these aid has been low in the 
region (Serieux, 2009). According to Maxwell 1994, direct foreign investment is instrumental in suppressing domestic entrepreneurship and therefore, leading to declined domestic investment. This is because foreigners use their superior knowledge, high level of advertising and economies of scale to drive out local competitors and suppress the growth of small scale enterprises. Maxwell further concludes that direct foreign investments leads to low rates of national savings, an increase in the current account deficits, lower rates of economic growth and investment rates.

In Kenya the government recognizing the fact that households should be main suppliers of finances that the economy needs for investment through their savings, the role of households saving has been recognized since independence despite the fact that there was an overreliance on foreign debt, and international institutions to stimulate domestic investments. However, the government realized that if rapid growth of the economy was to be maintained households should be the main financiers of investments through savings leading to the introduction of compulsory saving schemes like the National Social Security Fund. The development plans designed by the government, for example the 1999-2001, 2002-2008 plans, the government recognized the need to lower our propensity to consume and increase the saving rates in the country. A target was set to increase the domestic saving rate to over $25 \%$ of the GDP by the end of this planning periods (Republic of Kenya, 1997, 2002).

The new long term development blueprint commonly referred to as "VISION 2030" that covers the period of 2008-2030, targets to transform the economy from a low income country to a newly industrialised middle income country by the year 2030. This development blueprint envisions the growth of national income at the rate of $10 \%$ per annum from 2012 to 2030 . One of the challenges that the government anticipated was the raising of the level of domestic investments that was at $20 \%$ in 2007 to $30 \%$ of the GDP by 2030 . The six sectors that were identified to help fuel this growth were, the financial sector, tourism, agriculture, manufacturing, wholesale and retail trade and business process outsourcing. The financial sector is very important in the process of transforming each of the above mentioned sectors because it provides the financial capital needed. The financial sector also helps in the promoting and mobilizing high level of savings for financing the country's investment needs. In order for the country to reduce the dependency on foreign savings, the vision targets to raise the gross national savings in Kenya from $13.7 \%$ of the GDP to about $30 \%$ of the GDP by 2030 . These increased savings are the ones to be used to fund the six sectors above thus achieving the desired economic growth levels by the year 2030 (Republic of Kenya, 2007).

A few other studies have also been done on the factors influencing saving behaviour, for example Mbuthia 2011 did a study on household saving decisions in Kenya, and Kibet et al 2009 conducted a study on determinants of household saving, with a focus on smallholder farmers, entrepreneurs and teachers in rural Kenya. Njunge 2011 did a study on gender and household saving. It's therefore evident that there is an inadequate literature on the factors determining saving and asset allocation decision of low income holders in urban areas, and hence creates the knowledge gap that this study seeks to fill. From the available literature it is still not clear about what makes the urban poor different in their saving patterns and asset allocation and what factors are associated with this decision making process. Therefore, the major aim of this study was to contribute to a growing body of research on saving behaviours by determining the factors that influence saving and asset allocation decisions among low income households in rural areas in Kenya.

\subsection{Statement of the problem}

The goal of the government of Kenya as is spelled out in Vision 2030 is to stimulate the rate of annual growth to over $10 \%$ every year till the year 2030, this kind of growth will enable the country to transform into a middle income economy. In order for the economy to achieve these goals and realize sustainable economic growth, capital formation should be mainly financed from domestically generated resources. This therefore, calls for an increase in national saving rate, however, the gross national saving rate was at $11.1 \%$ at the time of formulation of vision 2030, this is very low compared even to other countries in sub-Saharan Africa whose savings rate is $20.3 \%$ (Economy Watch, 2010).

Our government plans to increase the gross national savings to $30 \%$ of the GDP by the tear 2030, private savings are expected to increase to $25.5 \%$ forming the bulk percentage of the gross national savings. Household's savings form a large proportion of private savings and can be mobilized and made available for investments. It was therefore, important to understand the factors that influence the saving and asset allocation pattern among households.

Many studies had been carried out to try and understand the saving behaviours and patterns of households, for example a study my (Mbuthia 2011) looked at the households saving decisions in Kenya, Kibet et al (2009) looked at determinants of household saving among small holder farmers, entrepreneurs and teachers in rural Kenya. Given, Njunge (2011) looked at gender and household savings. As vision 2030 envisions bringing prosperity to all Kenyans at all levels, understanding the nature of households is important in designing policies to promote savings and investment. It's especially important to know the factors which influence saving 
behaviours and asset allocation decisions among low income holders in the country. A lot of studies have been carried out to try and understand the saving decisions of low income holders in rural areas, this study aims to examine the factors which influence saving decisions among low income households in rural areas by answering the following research questions.

\subsection{LITERATURE REVIEW \\ 2.1 Determinants of Saving and Asset Allocation Behaviour 2.1.1 Financial Literacy/information}

Financial literacy has been defined as the way in which people manage their money by looking at ways in which they invest, save, budget and use insurance (Mahdzan and Tabian, 2003). Still others have defined financial literacy as the ability to make informed judgments, effective decisions regarding the use and management of money, its being knowledgeable and assured in the areas of saving, spending and budgeting. The measures of financial literacy should be able to highlight an individual's circumstances rather than against the entire array of financial products and services some of which an individual will neither need nor use (Hogarth, 2002). Researchers have concluded that financially literate people would know how to manage their money, be able to understand how financial institutions work and have a range of analytical skills. Furthermore, they would know how they should handle their financial affairs and how to be responsible financially (Beal and Delpachtra 2003).

A lot of studies have been conducted to measure the degree and spread of financial literacy, for example a study in America by (Lusardi and Mitchell, 2007), showed that people with a low level of education, AfricanAmericans, females and Hispanics showed low levels of financial literacy, this in turn affects the financial decision making process. The results of this study pointed out that people with low-levels of financial literacy failed to plan properly for their retirement, exhibited poor borrowing behaviour, and they participated less in the stock market. Another study conducted in the UK on financial literacy with a focus on people renting government owned houses, the young, students and single parents. The study asked participants questions about money management, their buying and selling attitudes, and their confidence in facing money issues. The study showed that single parents have less confidence in dealing with their financial problems but the majority in the other groups had good confidence. Another study conducted by Chen and Rolpe (1998) examined financial literacy amongst students in 14 American universities, the study linked the scores of individuals socio-economic and demographic attributes. The results of the study showed that young females with non-business majors and little work experience have very low degrees of financial literacy.

\subsubsection{Financial Institutions characteristics}

Ensuring access to financial services among rural poor population for augmenting agricultural production, alleviating poverty, and improving the efficiency of rural credit delivery systems has been an area of focus in the planning process the developing world including Tanzania (Kilimo Kwanza- Agriculture First Vision, URT, 2009). Many of the developing countries governments believe that microfinance programs can alleviate financial liquidity constraints, stabilize consumption and thus impact both income and consumption for the poor, thereby augmenting the poor's welfare. The poor are expected to use financial services to invest in health and education, manage household emergencies, and meet the wide variety of other cash needs that they encounter. Proponents of microfinance schemes (Yunus, 2006; Littlefield et al., 2003).

Morduch, 2009) believe that microfinance around the world can increase household income, build assets, and reduce vulnerability of poor households and individuals. It is further believed that access to financial services among the poor households can also translate into better nutrition and improved health outcomes, such as higher immunization rates. Microfinance institutions services can also allow poor people to plan for their future and send more of their children to school for longer make women more confident and assertive and thus better able to confront gender inequalities (Makombe et al., 1999; Tchouassi, 2011; Umara et al., 2011). Furthermore microfinance institutions seek to stimulate saving behaviour, building asset base of poor households despite the general belief that there is low demand for savings instruments amongst the poor (CGAP, 2004; Basu, 2008).

Some researches on savings of the poor have shown that the poor do save and look for savings outlets for their savings (Robinson, 2001; Rosenzweing, 2001). Savings services provided by microfinance institutions have included fixed deposit, membership shares (compulsory savings) and normal savings (Koveous, and Randhawa, 2004). These products can improve creditworthiness of members thereby improving household borrowing chances especially during crisis (Adjei et al., 2009; Robinson, 2001). The analyses on the impact of microfinance institutions on saving behaviour of rural households provide some evidence for rejoicing. Econometric results point to a positive and statistically significant impact of microfinance program on saving behaviour among farm households. Savings in financial assets increases with microfinance program membership duration. 
Results suggest that household access to MFIs has a positive and significant impact on financial savings of farm household. Previous empirical literature suggests that underdeveloped rural financial markets in developing countries retarded economic growth and development. The assumption has been, rural poor are too poor to save. This assumption limits the extension of saving services to rural areas by most of mainstream banks. However, this study shows that rural farm households are able to save/invest in financial assets (Deposits, shares and other securities). This signifies the importance of appropriate saving/financial investments facilities to rural farm households in Tanzania. The study also shows that savings are determined by the type of MFIs, for which a household is a member, and location characteristics of the household. Farm households who are SACCO's members are more likely to make savings than other farm household with membership elsewhere. Both MFIs characteristics variables and location characteristics reflect the influence of transaction costs associated with savings in MFIs.

\subsubsection{Fiscal policy}

When taxes are increased directly, the income available to a household reduces while increment of taxes are increased indirectly then, the purchasing power of existing personal income is lowered. In one way or another, the potential and propensity to save is negatively affected, since the consumption tendency is generally highly inelastic with respect to income and the case for African countries in general and Kenya in particular is that average personal income is grows at a very slow rate and in some cases it is almost stable. In this case an increase in the taxes would not only prevent household savings but it might also lead to negative personal savings if some income-earners were induced to disinvest accumulated wealth in order to counterbalance the reduction in income (actual or in purchasing power) allocated to current consumption expenditure (Kodom, 2013).

Kodom (2013) believes that the amount to be gained by the interest rate, even if it is high, normally has little economic significance to savers, who deposit or invest amounts in a small average volume. Therefore, the saving behaviour is not influenced by the interest rate and savers do not seem to be particularly interest-sensitive. However, the accumulation of savings at the household level appears to be strongly influenced by the following factors: the need for insurance, the need for credit, the feeling of social obligation, and the planning of future expenditure (both for consumption and investment). Again, this is indirectly proved by the performance of indigenous associations (both the savings and mutual-aid kind) and by the behaviour of adherents. In such an environment, it becomes understandable that the interest rate cannot provide a sufficient motivation to save or to deposit savings into a bank. In fact, by saving with an indigenous association (or even a credit union) the household obtains security, credit and social standing inside the local community which is more important than interest earned from the said savings.

\subsubsection{Household head's demographic}

Chakrabarty et al (2008) emphasized that when education is relatively stable across an individual's lifetime it tends to have a positive correlation with the permanent income.

It was also observed that in 1991/2, higher levels of education (tertiary) significantly increased the probability of savings but this couldn't hold for 1998/9. Thus 'the probability of savings increases as one attains tertiary education but the marginal effect was not significant'. Schooling may enable people to appreciate the finer things in life or to be more efficient in making consumption decisions (Solmon, 1975). Generally it has been argued that one purpose of education is to instill an analytical ability in students. "Returns to saving will be high when the saver can estimate and analyze the effects of current and future prices of goods, current and expected returns to various financial assets, the investment alternatives available, and current and future conditions of other aspects of the economy. It is possible that people with the same income can purchase equally good investment data and advice. However, it would seem that an educated person can do whatever the less analytical person can do and more" (Solmon, 1975).

\subsubsection{Financial literacy and savings and asset allocation behaviour}

The study by Kiiza and Pederson (2002) looked at factors influencing a decision to save in a bank account only. The current study will not only focus on bank accounts but other saving instruments that can be used by low income households in Kenya. Carpenter and Jensen (2002) carried out a study to examine the factors relevant to individual choice of formal and informal saving instrument in Pakistan, Pakistan is a country whose financial system is governed by the Islamic Sharia law. They considered the factors that affect household decisions to save in the banks and BISIs, a type of ROSCA. They used data from Pakistan integrated household survey, which sampled a total of 4800 households using multistage stratified random sampling. The study used both descriptive analysis and regression analysis. They used a general reduced form bivariate probit for participation in each of the methods. This study found out that 30 percent and 18 percent of urban households used BISIs and banks, respectively, while 10 percent and 15 percent of rural households used BISIs and banks, respectively. The study 
also found out that increase in years of education raised the likelihood of having a bank saving deposits. Level of income positively affected the participation in both BISIs and bank. Education level, numeracy and literacy level positively affected the bank use but not BISI use. Greater education implied better understanding of availability and benefits of banks. The use of banks and BISIs was positively affected by the number of female adults in a household, with use of BISIs being greater than use of banks in households that had more women. The BISI use was lower in rural areas as compared to urban areas mainly due to BISI formation being more conducive in urban areas due to regular incomes and more dense households as compared to rural areas. Households with more stable incomes had greater use of BISIs as compared to those without stable incomes. At higher levels of income, long term formal savings mechanisms became more desirable.

Bank use took place even among poor rural households. The low incidence of bank participation and high use of informal saving mechanisms pointed to a large pool of resources that could be mobilized into the formal sector. The study recommended the need to consider the existing forms of financial intermediation and how they could be transited into formal mechanisms. In the Pakistan study, literacy level in the household was the major hindrance to bank use, hence the need to think of banking structures and technologies that would not require literacy was recommended (Carpenter and Jensen, 2002).

The study was conducted in Pakistan, a country whose financial system is governed by the Islamic Sharia'h law. Much as the Kenya Commercial Bank and Barclays Bank of Kenya and some other two Islamic Banks have introduced Shari'ah compliant banking, the Kenya financial systems operate under different laws and there is need to explore the factors affecting the choice of saving in formal and informal financial institutions, and explore the differences inherent. The study considered savings in banks to represent savings in FFIs and savings in BISIs to represent savings in IFIs. The current study did not only consider savings in banks, but also savings in other types of formal financial institutions. In addition, the study examined determinants of decision to save in all types of informal financial institutions and semi-formal financial institutions.

\subsubsection{Financial institution Characteristics and savings and asset allocation}

A study conducted by (Chowa, Masa and Ansong, 2012) in Uganda analysed the determinants of saving among low-income individuals in rural Uganda. The results from the study indicated that the institutional theory of saving has independent and significant explanatory power in saving outcomes in Uganda. Unlike the institutional theory of saving, which emerged from studies of saving behaviors of low-income individuals and households, individual- oriented and sociological perspectives were not developed to explain saving by low-income populations. Findings also suggest that institutional structures of saving matter to low-income individuals in rural Uganda. Given access to the same institutional support for saving and asset building that their wealthier counterparts use, low-income individuals can be in a position to save and accumulate assets. Unlike the other theoretical perspectives that may have limited practical implications, institutional theory of saving can directly inform future programs and policies designed to promote financial inclusion and help low-income individuals and families save and build assets.

The study also identified the major hindrances to opening of bank accounts among households. The study found out that resource barriers, institutional barriers and informational barriers were the major hindrances to opening the accounts in that order. This study by Mbuthia (2011) looked at the factors influencing household's decision to save in formal, semi-formal or informal saving institutions in Kenya. This current study will look at how access to financial institutions will influence households in the lower income bracket in their saving and asset allocation decisions.

A study conducted by Rogg (2000) among micro-entrepreneurs looked at the effect of credit availability on the level of financial savings in two types of financial institutions, MFIs and FFIs in Ecuador, Paraguay and Salvador. Using a probit model they looked at the factors affecting an individual's decision to save regularly. Age, education and other income were found to be statistically significant in increasing the likelihood of saving regularly. Micro-entrepreneurs who had access to credit were likely to save more than those without access to credit. In addition, those who had access to credit, were more regular savers compared to those who do not borrow. The study found out that there exists a positive relationship between obtaining credit and saving regularly in MFIs and FFIs. However, Rogg further noted that borrowers from MFIs showed a more regular saving habit in response to credit compared to borrowers from FFIs. Even though the overall savings could fall when credit was extended, the share of savings held in deposit accounts could still rise due to the indirect impact of introducing micro-entrepreneurs to FFIs. Most recipients of loans had been excluded from other services provided by the FFIs. When micro entrepreneurs were given loans, they made regular repayments to the financial institutions. The repeated interactions with FFIs as they repaid loans introduced them to FFIs, increased their understanding on operations and services offered by FFIs and they also gained confidence in the FFIs. This increased the probability that funds that would have been kept in cash and in other illiquid assets were deposited in the FFIs. The loans could also raise the income of borrowers hence enabling them to save more. 
Rogg (2000) looked at the effect of credit availability on the level of financial savings in two types of financial institutions, MFIs and FFIs in Ecuador, Paraguay and Salvador. The current study will examine how access to financial institutions influence the saving rate and asset allocation decision in Kenya. A study conducted by Kiiza and Pederson (2002) in Uganda looking for identify factors that influenced decision to open a savings deposit account and factors affecting the net savings of a household. In this study Cross sectional data was collected from central, eastern and western regions of the country in 1996 and 1997, covering a total of 370 households. The households under study were observed to be making two separate decisions. The first decision related to whether or not to choose to acquire or not to acquire a deposit instrument for example a savings account in a financial institution, this represented choice between financial and non-financial assets. This was modeled using a logistic function. The second decision was to decide how much to save once a saving instrument had been acquired given the minimum deposit requirement of the financial institution. This was modeled by specifying and testing the household net saving deposit function. The study assumed that a household choice to acquire a saving deposit instrument was influenced by attributes of saving deposit that included the level of information available to the household on banking activities, proximity of the institution and number of banks in the household's locality. In addition, the choice was also influenced by the characteristics of the head of the household that included the level of income, type of occupation, age, work experience and the education. A logistic function was used to predict the probability of a household opening a saving deposit account in a financial institution

Institutional accessibility was affected by availability of financial information. Probability of a household in acquiring a saving deposit increased with increase in information about the banking services. Availability of financial information was a major catalyst in increasing household savings mobilization. A household's probability of acquiring a saving deposit increased dramatically when households were well informed on banking sector. They recommended that for savings mobilization to be effective, households needed awareness on financial investment opportunities available. They observed that advertising and other forms of communication on financial services were crucial in increasing mobilization of savings among households. In addition, they noted that financial institutions could influence choice to save and amount saved through appropriate incentives, instruments and improvements in accessibility to their services.

A study conducted by Mbuthia (2011) investigated households saving decisions in Kenya the study analyzed the factors that affect the decision to save in formal financial institutions(FFIs), semi-formal financial institutions(SFFIs and informal financial institutions(IFIs), using a separate logistic regression for each type of financial institution. The study found that credit availability, level of financial information on FFIs, location of the household in an urban area, and household head having an education level of secondary and above increased the probability of saving in FFIs. On the other hand, perception that rate of interest on savings held in semiformal financial institutions was high and a large household size, credit availability high level of financial information on operations of SFFIs encouraged householdse decision to save in SFFIs. Like in the FFIs and the SFFIs, the credit availability in IFIs and high level of financial information regarding IFIs played the most significant role in increasing the probability of saving in IFIs. An increase in the age of the household head and size of the household similarly led to increase in the probability of saving in IFIs. Location of the household in an urban area, increased level of financial information about FFIs, increased bank density in urban areas, deriving main income from formal sector, increased transaction cost to nearest banks and the gender of the household being male reduced the probability of a household saving in IFIs. The sex of the head of the household had a statistically insignificant coefficient in the decision to save in FFIs and SFFIs. However, when making a decision to save in IFIs, it had a statistically significant coefficient, with the probability of saving in IFIs being higher if head of household was female. This was explained by the fact that majority of those who were saving in IFIs were females.

\subsubsection{Fiscal policy and savings and asset allocation behaviour}

Rogg (2000) found that micro-entrepreneurs rarely deposited savings in FFIs citing high minimum deposit requirement, liquidity, and high transaction cost, inconvenient banking location and opening hours, unfamiliarity with savings products as the major hindrances. They also noted that the banks were not offering them the whole range of services that were enjoyed by wealthier clients. In addition, savings in banks was discouraged by economic and political instability, and high levels of inflation. The study noted that the low income households relied on informal financial institutions for their savings and credit needs. The IFIs only acted as a substitute for some of the financial services offered by FFIs. Hence, the low income households were unable to smooth consumption efficiently and conveniently.

Amimo et al., (2003) conducted a study in rural Mozambique to examine the potential for financial savings among rural Mozambique households. The study was conducted in a sample of 113 households selected from one of the provinces in the country. The study used ordinary least squares method for estimating the household financial savings function using level of income, physical and financial wealth, size of household, dependency 
ratio, age of head of household, education level of household head and gender as the independent variables. The income level was found to increase the savings level of a household while the household size, years of schooling and gender of household being female were found to decrease the level of financial savings in a household. This study was conducted using a small sample, in one of the regions within the country and only a few independent variables were included. The current study was done using a more representative sample collected from households all over the Kenya. The study not only looked at the determinants of savings level but also what influences where those savings are kept.

Aryeetey (2004) conducted a study in Ghana seeking to ascertain the assets kept by households and the relationship between choice of assets and the socio economic characteristics of rural households. In the face of expected income shocks, farming households tried to smooth consumption through diversification of crops and the general set of economic activities that a household engaged in. Non-farm activities provided an important share of household incomes. This technique of diversifying crops was extended by diversifying holding of physical and real assets. In rural areas, households diversified by holding productive and not-so-productive real assets. In urban areas, diversification was in the types of financial assets that were held.

Study findings indicated that the low income earners concentrated their asset portfolio on livestock and farms, middle income earners mainly held land and non-farm enterprises, while the high income earners mostly held financial savings in banks. Non-farm enterprise assets were 47 percent in urban areas and 16 percent in rural areas. The younger people, 11-40 years of age, were seen to own more non-farm enterprise assets as compared to the older 40-60+, whose portfolio was mainly concentrated on houses and land. This implied that the young had a greater consciousness on rates of return on different assets, hence more involvement in non-enterprise activities. Female headed households tended to concentrate more on non-farm enterprises while male headed households concentrated more on livestock. Women had more loans and fewer saving in their portfolio as compared to men, possibly due to more involvement in non-farm enterprises that required more capital.

The study confirmed study findings in Pakistan (Carpenter and Jensen, 2002) and in Uganda (Kiiza and Pederson, 2002) that households with more educated heads tended to utilize the formal savings mechanisms more as compared to those with less education who tended to concentrate on livestock and susus (a type of ROSCA). The households who had access to major or regular markets had a more diversified portfolio combining agricultural and non-agricultural assets. Chandararot and Dannet (2007) conducted a study in Cambodia in 2007 using a sample of 801 households spread over eight provinces in the country. The main objective was to identify the savings rate, the savings mechanisms and reason for their use among poor households. Savings were defined as difference between income and consumption spending. Among the 497 households who had positive savings, 67 percent kept their surplus income in cash and gold, 29 percent kept it in livestock, 3 percent kept it in „Tongtin a type of ROSCA, 0.1 percent kept it in savings groups facilitated by NGOS operating in the country, and only 0.002 percent kept their savings in a bank. Asked why they did not use formal deposit taking institutions for saving, 89 percent said they had no cash to save, 15 percent said they were not aware of the financial institutions, 4 percent did not trust FFIs, 3 percent felt interest rates were low and withdrawal was difficult, while 1 percent felt the FFIs were far away from home.

Cash and gold was preferred as a means of saving due to its low transaction cost, high liquidity and convenience, and to take care of the uneven income streams. Livestock was preferred as a means of food security, safeguarding against economic downtown and meeting urgent cash flow shortages such as payment of school fees. „Tongtins were mainly used to take advantage of future interest earnings and also for purposes of securing string less credit. Saving groups were used for purposes of building wealth and earning interest on savings. The study suggested that for saving products from banks and MFIs to be attractive to poor households, they should be located in convenient locations, establish good infrastructure, be flexible and treat household as one saver so as to take advantage of the various sources of income for household members.

The study looked at what affected choice of saving in each of the informal saving instruments and also in formal banks using descriptive statistics. Only low income households were used in the study in Cambodia and importance of each of the variables in affecting decision to save in informal and formal financial institutions was not estimated. The current study used all types of households and ensured that the importance of different variables in affecting decision to save in different financial institutions was explored.

Newman et al., (2007) conducted a study to determine factors affecting the decision of a household to save in formal and informal financial institutions and factors that affect the magnitude of financial savings among rural households in Vietnam. Data collected from a household survey was used and analyzed using descriptive statistics. The study found that wealthier households were more likely to save. The average age of household members was found to have negative effects on decision to save in line with the life cycle hypothesis. If the household had suffered an income shock, it was less likely to save. A comparison between savings participation in FFIs and IFIs showed that age had a negative effect on saving in IFIs but no effect on decision to save in FFIs, wealth had non-linear positive effects on savings in IFIs but no effect on savings in FFIs, while education had positive effects on decision to save formally. From the study, different factors influenced savings in FFIs and 
IFIs. An increase in income increased the amount of household savings. In addition, an increase in household size and receipts of assistance from children reduced the amount of household savings.

Newman et al., (2007) only used descriptive statistics to analyse factors affecting decision of a household to save in FFIs and IFIs. The current study used a logit model, which is a more intensive econometric analysis to examine factors affecting a decision to save in FFIs, SFFIs and IFIs. Bendig et al., (2009) conducted a study to examine the differences and similarities in the determinants of demand for formal financial loans, savings and insurance in 2008 among the rural households in Ghana. Majority of the low income households were concentrated in rural areas, with over 80 percent of the population engaging in farming activities and other small scale businesses. A total of 350 households were sampled from the central region in Ghana where only 5-6 percent of the population had access to formal financial institutions. The study showed that there was a strong positive correlation between the demand for savings, loans and insurance. The three formal financial products were shown to complement each other.

An increase in household size significantly increased the probability of demanding formal financial savings and loans, and this was explained by the need to build buffers against calamities. An increase in the age of head of household increased the probability of acquiring saving and insurance combined, acquiring all the three combined together, but for savings alone, age was not an important determinant. The probability of saving increased significantly with years of schooling. In addition when the land holding size and the asset index increased, the likelihood of saving in the combined three formal financial products also significantly increased, especially because such households were able to use the assets and land as collateral. Receipts of remittances from relatives/friends increased the probability of saving in FFIs but did not significantly affect the decision to acquire loans or insurance products. Households headed by females had a lower probability of demanding the savings product and also the other two products. Households deriving their income from the self-employment were less likely to demand formal savings and also loans and insurance, especially due to low and irregular incomes. Interestingly, households in close proximity to financial provider were less likely to demand savings and insurance products. This was explained by the fact that the financial providers did not make concerted efforts to take their outreach programmes to those near the financial institutions and instead took them to those far off. It was not just important to increase the supply of financial institutions, but in addition, there was need to build trust and increase financial literacy as suggested by Bendig et al., (2009). Those with higher exposure to risk were significantly less likely to demand the three formal financial products, possibly because they regarded the acquisition of the formal financial products as an additional risk.

Bendig et al., (2009) focused on the determinants of decision to save, take loans and also acquire insurance at the same time. The current study examined the factors affecting the decision to save in three different forms of financial institutions, FFIs, SFFIs, and IFIs. The variables in the study by Bendig et al.,(2009) that were found to statistically affect the decision to save only, a combination of savings and loans, savings and insurance, and all the three combined were included as explanatory variables in this study albeit with different definitions and measurements. These include age, age 2 , household

Kibet, et al., (2009) conducted a study in Nakuru, Kenya to investigate the determinants of household saving, using a sample of 359 households selected from seven divisions, which included teachers, businessmen and farmers in the area of study. The study estimated a household savings deposit function using ordinary least squares method. The dependent variable was household savings held in financial institution for over two months. The explanatory variables were gross income, dependency ratio, age of respondent, gender of respondent, occupation of respondent, rate of interest on savings, transport cost to and from financial institution of saving and credit access.

The study found out that saving was ranked on sixth among twelve items in the household budget hence it was not a residual as assumed by conventional economic theory. The coefficients of income, credit access, dependency ratio and age of respondent were found to be statistically significant in affecting the savings level. Household's savings increased with an increase in income while it was found to decrease as age of household head increased, as dependency ratio increased and as credit access increased. Businessmen were found to save significantly more than the farmers and the teachers. The current study estimated the household savings function using a sample of 6598 households distributed in all the regions of the country across all professions.

Boring (2010) conducted a study to examine motivations behind saving behavior and institutional choice using data collected from a sample of 2774 households in Uganda. The study surveyed the demand, utilization and access of savings in different types of financial institutions. The financial institutions were divided into four; formal, semi-formal, informal and non-institutional financial institutions. The data was analyzed using binomial probit regression model. The study included the following independent variables; place of residence, age in years, status of respondent in household, literacy, sex of respondent, marital status, level of education, primary 
source of income, presence of consultation when making financial decisions, trust of financial institutions, position in life relative to desired state, and the wealth of household relative to mean for the sample. All the independent variables except age of head of household were binary variables.

A total of five regression equations were estimated; one representing the decision to save or not, and the other four representing the decision to save in each of the four aforementioned financial institution. When making the decision to save or not, age of respondent in years, statistically reduced the probability of saving. On the other hand, respondent being the household head, literate and with a high education level, deriving income from formal employment, deriving income from entrepreneurial activities, life being close to desired state, and wealth being above the mean for the sample, all statistically increased the probability to save. When making a decision to save in FFIs, the respondent being the household head, married and households ${ }^{\text {ee }}$ wealth being above the mean of the sampled households, significantly increased the likelihood of saving in FFIs. All the other variables were not statistically significant.

When deciding to save or not in SFFIs, respondent residing in a rural area, being the household head, married, and householdse wealth being higher than the mean of sampled households, significantly increased the probability of saving in SFFIs. Other variables were not statistically significant. Probability to save in IFIs significantly increased when a household was residing in a rural area, respondent was the household head, was married and if they trusted the informal institutions. The other variables were statistically insignificant. In making a decision to save in the non-institutions, residing in a rural area, respondent being the household head and being married increased the probability of saving in non-institutions.

All the independent variables used in the study by Boring (2010) except age were binary. Some of the variables such as; credit availability, level of financial information, bank density, transaction time to nearest bank branch, size of household, sector of employment, and perception about rate of return paid in FFIs and SFFIs that have been shown to affect households' decision to save in a financial institution were not included in the study.

\subsubsection{Household head's demographic and savings and asset allocation}

A study conducted by Quartey and Blankson (2008) found out that females held more savings account than males (53.5\% against 46.5\%). It was observed that comparing this figure to that of earlier periods of 1992/1, showed that the proportion of males with savings account declined. Another study carried out by Denizer et al. (2000) where they were analyzing household savings in Bulgaria, Hungary, and Poland noted that households headed by women exhibit significantly higher savings rates than those of men in these three countries. Dupas and Robinson (2013) worked in collaboration with the Bumala village bank in Kenya and randomly provided small business owners with access to savings accounts. After a period of four to six months after account opening; women in the experiment group had 45 percent higher daily investment in their businesses than women in the comparison group. Thus, it can be concluded that women have the capacity to save in spite of being faced with a number of barriers.

On the other hand, some researchers have concluded that no gender difference in savings and investment behavior exists. For example, Zhong and Xiao (1995) found no gender difference in the dollar holdings of stocks. DeVaney and Su (1997) concluded that the determinants of retirement planning knowledge were similar for men and women, and Masters and Meier (1988) found no difference in the risk taking propensity of male and female entrepreneurs.

A number of studies have observed that household members who are less than 18 years hold greater proportion of the savings account. Even though the members below 18 hold a large proportion of savings account, those aged 60 years and above had the highest mean savings balance followed by those who are less than 18 years. This result contradicts the Life Cycle Hypothesis $(\mathrm{LCH})$ which predicts that working population accumulate savings whiles the young and the old consume past savings (Quartey and Blankson, 2008). Similarly, Chakrabarty et al (2008) in their analysis of the saving performance of Australia found results consistent to that of Quartey and Blankson (2008). The results of the study showed that households save more as heads become older. For example, the saving rates for households with heads aged 41-50, 51-60, and aged 61 or above were higher than those with heads aged 30 or below. This evidence runs contrary to the lifecycle theory of consumption. Lifecycle theory predicts that households should start dissaving as they age.

Chakrabarty et al (2008) also believed that savings of the households with heads over the age of 61 could be higher due to generous tax benefits of superannuation contributions. Another possible explanation behind this behaviour could be the increase in average life expectancy in Australia. Attanasio (1998) in his examination of the relationship between age cohort and personal savings in the United States using data from the Consumer Expenditure Surveys (CEX) from 1980 to 1991 found that age-savings profile is humped-shaped with the peak of savings occurring around age 57. However, Shultz (2005) who analysed the demographic determinants of savings in Asia found no significant relationship between savings and age composition. 
Elbadawi and Mwega (2000) analysed the determinants of private savings in sub-Saharan Africa. In addition they narrowed down to the savings experiences of Kenya, Zimbabwe and Botswana. Collective results of subSaharan Africa revealed that per capita Gross Private Disposable Income (GPDI) influenced private savings positively. Youth dependency ratio (the ratio of the population under 15 years to the population of those over 15 years) and urbanization (the proportion of the urban population to the total population) had negative and insignificant influence on savings.

Fisher (1965) has provided a list of personal characteristics that would seemingly influence time preferences and hence savings: foresight, self-control, a habit of thrift, concern over the uncertainty of life, concern for heirs, and concern for fashion and fads. The argument has generally been that these characteristics are influenced by education. Watts (1958) has pointed out that "high education may imply lower consumption, quite apart from the income correlation, if better educated people are more farsighted and therefore have stronger retirement motives. It has been argued that the higher the household size, the higher the consumption pattern and all things being equal, the lower the excess money left for consumption. Elfindri (1990) conducted a study to examine the demographic impact of family size on household savings in some part of central Sumatra in Indonesia. Using data from the 1987 Indonesian census, the results from the regression analysis show that the size of the household and the number of children at school going age negatively affect household savings. In contrast to the findings of Elfindri, Browning and Lusardi (1996) who analysed micro theories and data on household savings found that household size can have a positive effect on savings according to economies of scale. However, the composition of the family, rather than the size of the family per se, has a greater impact on savings. A young family member does not have the same effect on household savings as an elderly family member or an adult. The difference in the findings of Elfindri (1990) and Browning and Lusardi (1996) stems from the fact that Elfindri looked at household size in general whiles Browning and Lusardi extended their study to include composition. Thus, by composition, a household with many of its members working while have a positive effect on savings whiles a household with many of its members being dependents will have a negative effect on savings. But taking the household size as a whole, there is likely to be a negative relationship with savings.

Curley and Grinstein-Weiss (2003) in their comparative analysis of rural and urban saving performance in of Individual Development Accounts noted a variation between monthly net deposits between residents in these localities. Those in the urban areas had higher savings than those in the rural areas even though when other factors were controlled for, the difference was not statistically significant. Certain explanation were offered for this variations. First and foremost, a positive correlation was found to exist between average savings and financial education. Those who get access to financial education save more than those who do not and the urban areas are more privileged in this area than rural areas

Also access to financial institutions have been argued to influence savings. Savings among the "banked" people tend to be higher than the "unbanked" demonstrating that existing relationships with financial institutions may encourage higher saving amounts. The Federal Reserve Board's 1995 Survey of Consumer Finances further explained that many low-income individuals have little or no experiences with financial institutions. Several reasons have cited for being "unbanked" including charges imposed by financial institutions, difficulties of establishing credit, inconvenience due to location, lack of trust in institutions and lack of information regarding options available (Woodstock Institute, 2000).

Kiiza \& Pederson (2001) found that in Uganda, proximity of the financial institution to the household was associated with the probability of whether or not a household will open a formal saving account, as well as the level of net deposits among households owning a bank account. In the same study, urban households were more likely to open a deposit account than their rural counterparts. Higher transaction costs (due to reduced accessibility) were also found to have significant negative effects on the level of savings deposits among Ugandan (Kiiza \& Pederson, 2001) and rural Kenyan households (Dupas \& Robinson, 2009).

There are two conflicting views on issues relating to the ability of rural households to save or not. Proponents of these views were the traditional or old view and the new view. Those who argue from the traditional perspective argue that rural households are too poor and therefore they do not have the ability to save. Thus, they are unable to mobilize funds enough to have some for consumption and some excess left to save. Lambert and Lim (1986) explained that the inability of rural folks to generate enough funds to meet their consumption and excess to save emanate from the fact that rural livelihood is characterized by low productivity due to the use of traditional methods of farming. They do not have any savings to purchase new technologies for farming because of low income. It has also been added that rural households are poor and even if their incomes should increase over time due to some windfall, they will use that income on consumption and ceremonies (Adams, 1978; Von Pischke, 1978).

Unlike the traditional proponents, those who hold the modern viewpoint argue that it is untrue to assume that due to the traditional technologies the rural households use in production, they generate low income and are unable to meet their consumption pattern to get excess to save. They are of the viewpoint that rural households have the desire and capacity to save and where there are opportunities to encourage them to save, they respond positively 
to it like the households. They backed their position with some examples that unlike urban households, rural households predominantly save after harvest. Also the assumption that all rural based households are poor is totally wrong because the economics of rural households are characterized by heterogeneity in income levels. Thus, whiles some are poor, there are others who are also rich. Whiles the poor households save over a short period of time, the rich households are able to save over a long period of time and they usually have larger farms, higher income, better education and better jobs (Issahaku, 2011).

The amount of income one makes mostly depend on his or her occupation and as such, it has postulated that people whose occupation earn them higher incomes are able to have higher savings than those who are into menial jobs. In Ghana, Quartey and Blankson (2008) examined that majority of the households who save were engaged in agriculture but their mean savings were low. However those engaged in finance, insurance, real estate and business services had the highest mean current value of savings. Unlike Ghana, the findings from Dupas and Robinson (2013) work show that in Kenya, potential savers were market vendors, bicycle taxi drivers and selfemployed artisans who did not have a savings account but were interested in opening one. The findings from both studies show that those within the medium to lower income group tend to have more savings account but those within the higher income group held the highest mean savings. This stands to support the assertion that the poor have the desire to save (Issahaku, 2011).

Carpenter and Jensen (2002) used the level of income, variability of income, education level of head of household, sex composition of household, age of the head of household and locality of household as the independent variables. The current study examined the differences in use of formal, semi-formal and informal savings mechanisms across regions, income groups, sex, age groups, and educational levels, sectors of employment, varying levels of financial information and credit availability among Kenyan households

\subsection{METHODOLOGY}

\subsection{Research design}

The study employed a case study research design. It provided quantitative descriptions of the population. In this design, only one unit of the sample was studied in detail and the results used to generalize for other home stay facilities which have similar characteristics as the study unit. It was done among the tourists within the Tourists areas. It was cheap to undertake and collect large volumes of data within a very short time and the results from the sample can be inferred to the larger population (Trochim, 2006).

\subsection{Study area}

The research was carried out on rural households of Oyani Sub Location in Uriri Sub County, Migori County.

\subsection{Target population}

A population is the entire group of individuals, events or objects having common observable characteristics and which a researcher would like to generalize the results of a study (Mugenda and Mugenda, 2003). The study covered households in Oyani Sub Location. Statistics from the 2009 population and housing census indicated that there were 3569 households in the rural areas of Oyani as shown in table1.

Table 1: Target population

\begin{tabular}{lccc}
\hline Village & Male & Female & Total \\
\hline Katieno A & 320 & 358 & 678 \\
Kiatieno B & 309 & 337 & 646 \\
BAT & 337 & 423 & 760 \\
Oyani & 388 & 455 & 843 \\
Kachieng & 308 & 334 & 642 \\
Total & $\mathbf{1 6 6 2}$ & $\mathbf{1 9 0 7}$ & $\mathbf{3 5 6 9}$ \\
\hline
\end{tabular}

Source (KNBS, 2018)

\subsection{Sample size and sampling procedure}

A sample is a smaller group or sub-group obtained from the accessible population (Mugenda and Mugenda, 1999). This subgroup was carefully selected so as to be representative of the whole population with the relevant characteristics. Each member or case in the sample was referred to as subject, respondent or interviewees. Sampling is a procedure, process or technique of choosing a sub-group from a population to participate in the study (Ogula, 2005). 


\subsubsection{Sample size}

A sample is collection unit from the universe to represent it (Kothari, 2004). The sample size was determined using the Krejcie \& Morgan table (1970). According to the table, the target population of 3569 households corresponded to a sample size of 351 heads of the household.

\subsubsection{Sampling procedure}

The study employed both stratified and simple random sampling techniques. Stratified sampling ensured that Oyani Sub Location are proportionally represented. It was a technique that was used to identify the proportion in which to select from each district to form a sample. This technique was used to ensure that the target population is divided into different homogenous strata and each stratum represented in the sample in a proportion equivalent to its size in the population. Simple random sampling was used to ensure that each member of the target population has an equal chance of being included in the sample (Koul, 2002).

Table 2: Sampling Frame

\begin{tabular}{lccc}
\hline Village & $\begin{array}{c}\text { Population } \\
\mathbf{N}\end{array}$ & $\begin{array}{c}\text { Proportional allocation } \\
\left(\mathbf{N}_{\mathbf{i}} / \mathbf{N}\right) \mathbf{n}\end{array}$ & $\begin{array}{c}\text { Sample size } \\
\mathbf{n}_{\mathbf{i}}\end{array}$ \\
\hline Katieno A & 678 & $(678 / 3569) 351$ & 67 \\
Kiatieno B & 646 & $(646 / 3569) 351$ & 64 \\
BAT & 760 & $(760 / 3569) 351$ & 75 \\
Oyani & 843 & $(843 / 3569) 351$ & 82 \\
Kachieng & 642 & $(642 / 3569) 351$ & 63 \\
Total & $\mathbf{3 5 6 9}$ & $(3569 / 3569) 351$ & $\mathbf{3 5 1}$ \\
\hline
\end{tabular}

Source (Researcher, 2018)

\subsection{Data collection instruments}

The study used a set of structured questionnaires to collect data. Structured questionnaires were chosen because of ease of administration, and analysis. The chosen data collection instruments was considered appropriate for the study, because of the large sample size hence a respondent would felt comfortable to provide information anonymously. The questionnaire included both close-ended and multiple response open-ended questions.

\subsection{Data collection instruments}

A pilot test is a preliminary small scale study done to find out the feasibility and statistical applicability of the research design (Orodho and Kombo, 2002). A pilot study was conducted in the neighboring location to test the accuracy and consistency of the instruments of data collection in giving results. The pilot study was carried out at the households that were not included in the current sample.

\subsubsection{Validity of the data collection instruments}

Validity is the degree to which findings obtained from analysis of the data actually represents the phenomenon under study (Kothari, 2008). Therefore, content validity was employed. Content validity of the instruments was achieved by consulting the experts and the supervisors.

\subsubsection{Reliability of the data collection instruments}

Reliability is a measure of the consistency of the instrument in eliciting similar responses every time the instrument is utilized (Orodho, 2012). After pilot study, reliability was determined using Cronbach Alpha coefficient. The result obtained is as shown in Table 3.

Table 3: Reliability Test

Reliability Statistics

\begin{tabular}{|c|c|c|}
\hline & \\
\hline & Cronbach's Alpha & No. of Items \\
\hline Financial literacy & .741 & 4 \\
\hline Financial institution characteristics & .723 & 4 \\
\hline Fiscal policy & .773 & 4 \\
\hline Household head's demographic information & .717 & 4 \\
\hline
\end{tabular}

Source (Researcher, 2018) 
As shown in Table 3, financial literacy had four items whose Cronbach alpha coefficient was 0.741 , financial institution characteristics had four items with the Cronbach alpha coefficient of 0.723 , fiscal policy had four items with the Cronbach alpha coefficient of 0.773 and household head's demographic information had four items whose Cronbach alpha coefficient was 0.717. According to Gliem \& Gliem (2003), as a rule of thumb, acceptable alpha should be 0.70 or above. The Since the Cronbach alpha coefficients were higher than the minimum acceptable value $(0.7)$, thus, the items were considered reliable.

\subsection{Data analysis procedure}

After data collection, the questionnaires were sorted, edited, classified, coded and tabulated. Quantitative data analysis was adopted where both descriptive and inferential statistics were used. Descriptive statistical analysis involved summarizing large quantities of raw data, categorizing, rearranging and ordering data. Therefore, descriptive statistical techniques such as frequencies and percentages were applied and multiple linear regression analysis coefficient was adopted as the most appropriate inferential statistics technique. The data was presented in tables. The regression model was given as:

$Y_{i}=\beta_{1} X_{1}+\beta_{2} X_{2}+\beta_{3} X_{3}+\mu$

Where;

$\boldsymbol{\beta}_{\mathbf{1}}$ were the variable coefficient for the variables financial literacy, financial institution characteristics, fiscal policy and household head's demographic

$\mathbf{X}_{1}$ were the independent variables $\left(X_{1}=\right.$ financial literacy, $X_{2}=$ financial institution characteristics, $X_{3}=$ Fiscal policy and $\mathrm{X}_{4=}$ household head's demographic information)

$\mathbf{Y}_{\mathbf{i}}$ was the dependent variable (saving behaviour and asset allocation)

$\mu$ was the error term

\subsection{Findings}

\subsection{Response rate}

A total of 351 questionnaires were sent out to the respondents to fill. Of these questionnaires, 326 were returned for analysis. The returned 326 questionnaires accounted for 92.9\% response rate. According to Mugenda and Mugenda (1999), a response rate of $70 \%$ and above is adequate, thus a response rate of $92.9 \%$ was acceptable for data analysis. This was shown on Table 4.1.

Table 4: Response rate

\begin{tabular}{lcc}
\hline Questionnaire & Frequency & Percentage \\
\hline Administered & 351 & 100.0 \\
Returned & 326 & 92.9 \\
\hline
\end{tabular}

Source (Researcher, 2018)

4.2 Demographic Characteristics of the respondents

Among the demographic information sought were; gender, age, marital status, education level and dwelling place. The respondents were first asked to indicate their gender. This is shown in Table 5.

Table 5: The sector the business is involved in

\begin{tabular}{lcc}
\hline Category & Frequency & Percent \\
\hline Male & 119 & 36.5 \\
Female & 207 & 63.5 \\
Total & $\mathbf{3 2 6}$ & $\mathbf{1 0 0 . 0}$ \\
\hline
\end{tabular}

Source (Researcher, 2017)

As shown in Table 5, majority $207(63.5 \%)$ of the respondents were female while minority $119(36.5 \%)$ were males. This could be due to the fact that most men are in urban areas, thus, leaving women in the rural areas. Moreover, the respondents were asked to indicate their age. This is presented in Table 5. 
Table 6: Age

\begin{tabular}{lcc}
\hline Category & Frequency & Percent \\
\hline $18-27$ years & 29 & 8.9 \\
$28-37$ years & 96 & 29.4 \\
$38-47$ years & 127 & 39.0 \\
$48-57$ years & 58 & 17.8 \\
Over 57 years & 16 & 4.9 \\
Total & $\mathbf{3 2 6}$ & $\mathbf{1 0 0 . 0}$
\end{tabular}

Source (Researcher, 2017)

Table 6 above shows that majority $127(39.0 \%)$ of the respondents had 38-47 years old, 96(29.4\%) 28-37 years old, $58(17.8 \%$ ) $48-57$ years old, $29(8.9 \%) 18-27$ years and $16(4.9 \%)$ were over 57 years old. This implies that most of the households in the area are headed with people of 28-47 years old. Additionally, the respondents were asked to indicate their marital status. This is presented in Table 6.

Table 7: Marital status

\begin{tabular}{lcc}
\hline Category & Frequency & Percent \\
\hline Cohabiting & 1 & 0.3 \\
Divorced/separated & 3 & 0.9 \\
Widowed & 29 & 8.9 \\
Single & 46 & 14.1 \\
Married & 247 & 75.8 \\
Total & $\mathbf{3 2 6}$ & $\mathbf{1 0 0 . 0}$
\end{tabular}

Source (Researcher, 2018)

Table 7 majority $247(75.8 \%)$ of the respondents were married, 46(14.1\%) single, 29(8.9\%) widowed, 3(0.9) divorced/separated and $1(0.3 \%)$ separated. This implies that most of the households in the rural areas consist of married persons. The respondents were further asked to indicate their level of education. This is presented in Table 8 .

Table 8: Highest level of education

\begin{tabular}{lcc}
\hline Category & Frequency & Percent \\
\hline No school & 18 & 5.5 \\
Primary & 141 & 43.3 \\
Secondary & 117 & 35.9 \\
Tertiary college & 46 & 14.1 \\
University & 4 & 1.2 \\
Total & $\mathbf{3 2 6}$ & $\mathbf{1 0 0 . 0}$ \\
\hline
\end{tabular}

Source (Researcher, 2018)

Table 8 majority $141(43.3 \%)$ of the respondents had primary level of education, $117(35.9 \%)$ secondary, $46(14.1 \%)$ tertiary college, $18(5.5 \%)$ no formal school and $4(1.2 \%)$ had university level. This implies that most 
of the heads of the households have either primary or secondary level of education. This could be due to the fact that most of those who have high level of education are employed in the urban. Lastly, on the demographic information, the respondents were asked to indicate their dwelling place. This is presented in Table 9.

Table 9: Dwelling place

\begin{tabular}{lcc}
\hline Category & Frequency & Percent \\
\hline Own house & 289 & 88.7 \\
Rented house & 20 & 6.1 \\
Rent free & 17 & 5.2 \\
Total & $\mathbf{3 2 6}$ & $\mathbf{1 0 0 . 0}$
\end{tabular}

Source (Researcher, 2018)

Table 9 majority $289(88.7 \%$ ) of the respondents lived in their own houses, $20(6.1 \%)$ rented houses and $17(5.2 \%)$ in rent free houses. This is because in the rural areas most people live in their inherited ancestral land, thus, own their houses.

4.3 Descriptive statistics analysis the savings and asset allocation behaviour among low income individuals in the rural areas.

For the analysis of the objective, frequencies and percentages were employed as the preferred descriptive statistical techniques. This is presented as per specific objective.

\subsection{Relationship between financial literacy and saving and asset allocation behaviours}

The study examined the relationship between financial literacy and saving behaviours and asset allocation decision in rural Kenya: A case of Oyani Sub Location, Kenya. The analysis, therefore, opens with the descriptive statistics (frequency and percentage) for the level of agreement on a five point Likert scale of the financial literacy (Table 10). Where; $1=$ strongly disagree, $2=$ Disagree, $3=$ Undecided, $4=$ Agree and $5=$ Strongly Agree.

Table 10: Financial literacy and savings and asset allocation behaviour

\begin{tabular}{|c|c|c|c|c|c|c|c|}
\hline Statement on financial literacy & & SD & D & $\mathbf{U}$ & $\mathbf{A}$ & $\mathbf{S A}$ & Total \\
\hline Understanding on how financial & $\mathrm{F}$ & 29 & 21 & 26 & 133 & 117 & 326 \\
\hline asset allocation decisions & $\%$ & 8.9 & 6.4 & 8.0 & 40.8 & 35.9 & 100.0 \\
\hline Being knowledgeable in the areas of & $\mathrm{F}$ & 3 & 49 & 20 & 133 & 121 & 326 \\
\hline $\begin{array}{l}\text { saving, spending and budgeting } \\
\text { increases saving and asset allocation } \\
\text { decisions }\end{array}$ & $\%$ & 0.9 & 15.0 & 6.1 & 40.8 & 37.1 & 100.0 \\
\hline Knowledge on how to handle financial & $\mathrm{F}$ & 10 & 9 & 51 & 102 & 154 & 326 \\
\hline $\begin{array}{l}\text { affairs and how to be responsible } \\
\text { financially increases saving and asset } \\
\text { allocation decisions }\end{array}$ & $\%$ & 3.1 & 2.8 & 15.6 & 31.3 & 47.2 & 100.0 \\
\hline Ability to make informed judgments & $\mathrm{F}$ & 8 & 35 & 18 & 98 & 167 & 326 \\
\hline $\begin{array}{l}\text { and effective decisions regarding the } \\
\text { use and management of money } \\
\text { enhances saving and asset allocation } \\
\text { decisions }\end{array}$ & $\%$ & 2.5 & 10.7 & 5.5 & 30.1 & 51.2 & 100.0 \\
\hline
\end{tabular}

\section{Source (Researcher, 2018)}

Table10 shows that $133(40.8 \%)$ of the respondents agreed with the statement that understanding on how financial institutions work improved saving and asset allocation decisions, $117(35.9 \%)$ strongly agreed, $29(8.9 \%)$ strongly disagreed, $26(8.0 \%)$ of the respondents were undecided and $21(6.4 \%)$ of the respondents disagreed with the statement. The study findings suggested that most $250(76.7 \%)$ of the people living in the rural areas opined that understanding on how financial institutions work improved saving and asset allocation decisions. This supports the finding of Chen and Rolpe (1998) that understanding on how financial institutions work improved saving and asset allocation decisions. This implies that for enhance saving and asset allocation decisions, it is important to understanding on how financial institutions work.

Similarly, $133(40.8 \%)$ of the respondents agreed with the statement that being knowledgeable in the areas of saving, spending and budgeting increased saving and asset allocation decisions, 121(37.1\%) strongly agreed, 
$49(15.0 \%)$ disagreed, $20(6.1 \%)$ of the respondents were undecided and $3(0.9 \%)$ of the respondents strongly disagreed with the statement. It emerged from the study that most $254(77.9 \%)$ of the people living in the rural areas indicated that being knowledgeable in the areas of saving, spending and budgeting increased saving and asset allocation decisions. This implies that being knowledgeable in the areas of saving, spending and budgeting increases saving and asset allocation decisions as it will enable one to make prompt decision. This concurs with the findings of Lusardi and Mitchell (2007) who showed that people with a low level of education, AfricanAmericans, females and Hispanics showed low levels of financial literacy, this in turn affects the financial decision making process.

Additionally, 154(47.2\%) of the respondents strongly agreed with the statement that knowledge on how to handle financial affairs and how to be responsible financially increased saving and asset allocation decisions, $102(31.3 \%)$ agreed, 51(15.6\%) of the respondents were undecided, 10(3.1\%) strongly disagreed and $9(2.8 \%)$ of the respondents were in a disagreement with the statement. The study findings suggested that majority $256(78.5 \%)$ of the people living in the rural areas believed that knowledge on how to handle financial affairs and how to be responsible financially increased saving and asset allocation decisions. This implies that for increased saving and asset allocation decisions, there should be a knowledge on how to handle financial affairs and how to be responsible financially. This is in line with the findings of Carpenter and Jensen (2002) that greater education implied better understanding of availability and benefits of banks.

Lastly, $167(51.2 \%)$ of the respondents strongly agreed with the statement that ability to make informed judgments and effective decisions regarding the use and management of money enhanced saving and asset allocation decisions, $98(30.1 \%)$ agreed, 35(10.7\%) disagreed, 18(5.5\%) of the respondents were undecided and $8(2.5 \%)$ of the respondents strongly disagreed with the statement. It emerged from the study that most $265(81.3 \%)$ of the people living in the rural areas opined that ability to make informed judgments and effective decisions regarding the use and management of money enhanced saving and asset allocation decisions. This supports the findings of Carpenter and Jensen (2002) that need to think of banking structures and technologies that would not require literacy was recommended.

\subsection{How financial institution's characteristics influence saving and asset allocation behaviours}

The study identified the influence of financial institutions' characteristics on saving behavior and asset allocation in rural Kenya: A case of Oyani Sub Location, Kenya. The analysis, therefore, opens with the descriptive statistics (frequency and percentage) for the level of agreement on a five point Likert scale of the financial institution's characteristics (Table 11). Where; 1=strongly disagree, 2=Disagree, 3=Undecided, 4= Agree and 5= Strongly Agree.

Table 11: Financial institution characteristics and savings and asset allocation behaviour

\begin{tabular}{|c|c|c|c|c|c|c|c|}
\hline $\begin{array}{l}\text { Statement on financial institution } \\
\text { characteristics }\end{array}$ & & SD & D & $\mathbf{U}$ & $\mathbf{A}$ & SA & Total \\
\hline \multirow{2}{*}{$\begin{array}{l}\text { The financial institution } \\
\text { accessibility/location enhances saving } \\
\text { and asset allocation decisions }\end{array}$} & $\mathrm{F}$ & 43 & 22 & 14 & 106 & 141 & 326 \\
\hline & $\%$ & 13.2 & 6.7 & 4.3 & 32.5 & 43.3 & 100.0 \\
\hline \multirow{2}{*}{$\begin{array}{l}\text { The interest rate charged by the } \\
\text { financial institution determines saving } \\
\text { and asset allocation decisions }\end{array}$} & $\mathrm{F}$ & 16 & 35 & 16 & 105 & 154 & 326 \\
\hline & $\%$ & 4.9 & 10.7 & 4.9 & 32.2 & 47.2 & 100.0 \\
\hline \multirow{2}{*}{$\begin{array}{l}\text { The financial institution credit } \\
\text { availability enhances saving and asset } \\
\text { allocation decisions }\end{array}$} & $\mathrm{F}$ & 10 & 9 & 27 & 100 & 180 & 326 \\
\hline & $\%$ & 3.1 & 2.8 & 8.3 & 30.7 & 55.2 & 100.0 \\
\hline \multirow{2}{*}{$\begin{array}{l}\text { The financial institution minimum } \\
\text { deposit requirements determines saving } \\
\text { and asset allocation decisions }\end{array}$} & $\mathrm{F}$ & 11 & 30 & 13 & 129 & 143 & 326 \\
\hline & $\%$ & 3.4 & 9.2 & 4.0 & 39.6 & 43.9 & 100.0 \\
\hline
\end{tabular}

\section{Source (Researcher, 2018)}

Table 11 shows that $141(43.3 \%)$ of the respondents strongly agreed with the statement that the financial institution accessibility/location enhanced saving and asset allocation decisions, 106(32.5\%) agreed, 43(13.2\%) strongly disagreed, $22(6.7 \%)$ disagreed and $14(4.3 \%)$ of the respondents disagreed with the statement. The study findings suggested that most $247(75.8 \%)$ of the people living in the rural areas opined that the financial institution accessibility/location enhanced saving and asset allocation decisions. This implies that accessibility/location of the financial institution enhances saving and asset allocation decisions. This supports the finding of Chowa, Masa and Ansong (2012) that given access to the same institutional support for saving and 
asset building that their wealthier counterparts use, low-income individuals can be in a position to save and accumulate assets.

Similarly, 154(47.2\%) of the respondents strongly agreed with the statement that the interest rate charged by the financial institution determined saving and asset allocation decisions, 105(32.2\%) agreed, 35(10.7\%) disagreed, $16(4.9 \%)$ strongly disagreed and similar $16(4.9 \%)$ of the respondents were undecided on the statement. It emerged from the study that most $259(79.4 \%)$ of the people living in the rural areas indicated that the interest rate charged by the financial institution determined saving and asset allocation decisions. This implies that low interest rates will attract more people as compared to high interest rates. This concurs with the findings of Rogg (2000) that interest rate charged by the financial institution determined saving and asset allocation decisions.

Additionally, $180(55.2 \%)$ of the respondents strongly agreed with the statement that the financial institution credit availability enhanced saving and asset allocation decisions, 100(30.7\%) agreed, 27(8.3\%) of the respondents were undecided, $10(3.1 \%)$ strongly disagreed and $9(2.8 \%)$ of the respondents were in a disagreement with the statement. The study findings suggested that majority $280(85.9 \%)$ of the people living in rural areas believed that the financial institution credit availability enhanced saving and asset allocation decisions. This implies that when the credit is always available in the financial institution, saving and asset allocation decisions will be improved. This is in line with the findings of by Mbuthia (2011) that credit availability, level of financial information on FFIs, location of the household, and household head having an education level of secondary and above increased the probability of saving in FFIs.

Lastly, $143(43.9 \%)$ of the respondents strongly agreed with the statement that the financial institution minimum deposit requirements determined saving and asset allocation decisions, 129(39.6\%) agreed, 30(9.2\%) disagreed, $13(4.0 \%)$ of the respondents were undecided and $11(3.4 \%)$ of the respondents strongly disagreed with the statement. It emerged from the study that most $272(83.5 \%)$ of the people living in the rural areas opined that the financial institution minimum deposit requirements determined saving and asset allocation decisions.

\subsection{How fiscal policy influence saving and asset allocation behaviours}

The study evaluated how fiscal policy influenced saving and asset allocation in rural Kenya: A case of Oyani Sub Location, Kenya. The analysis, therefore, opens with the descriptive statistics (frequency and percentage) for the level of agreement on a five point Likert scale of the fiscal policy (Table 4.9). Where; $1=$ strongly disagree, $2=$ Disagree, $3=$ Undecided, 4= Agree and 5= Strongly Agree.

Table 12: Fiscal policy and savings and asset allocation behaviour

\begin{tabular}{|c|c|c|c|c|c|c|c|}
\hline \multicolumn{2}{|l|}{ Statement on fiscal policy } & \multirow{2}{*}{$\begin{array}{c}\text { SD } \\
32\end{array}$} & \multirow{2}{*}{ D } & \multirow{2}{*}{$\frac{\mathbf{U}}{43}$} & \multirow{2}{*}{$\begin{array}{l}\mathbf{A} \\
108\end{array}$} & \multirow{2}{*}{$\begin{array}{l}\text { SA } \\
119\end{array}$} & \multirow{2}{*}{$\begin{array}{r}\text { Total } \\
326\end{array}$} \\
\hline The tax cut enhances saving and asset & $\mathrm{F}$ & & & & & & \\
\hline & $\%$ & 9.8 & 7.4 & 13.2 & 33.1 & 36.5 & 100.0 \\
\hline \multirow{2}{*}{$\begin{array}{l}\text { Increased government spending } \\
\text { enhances saving and asset allocation } \\
\text { decisions }\end{array}$} & $\mathrm{F}$ & 22 & 44 & 30 & 110 & 120 & 326 \\
\hline & $\%$ & 6.7 & 13.5 & 9.2 & 33.7 & 36.8 & 100.0 \\
\hline \multirow{2}{*}{$\begin{array}{l}\text { Regulation of inflation by the } \\
\text { government enhance saving and asset } \\
\text { allocation decisions }\end{array}$} & $\mathrm{F}$ & 3 & 13 & 44 & 103 & 163 & 326 \\
\hline & $\%$ & 0.9 & 4.0 & 13.5 & 31.6 & 50.0 & 100.0 \\
\hline \multirow{2}{*}{$\begin{array}{l}\text { Adjustment of interest rates by the } \\
\text { government enhances saving and asset } \\
\text { allocation decisions }\end{array}$} & $\mathrm{F}$ & 7 & 27 & 9 & 149 & 134 & 326 \\
\hline & $\%$ & 2.1 & 8.3 & 2.8 & 45.7 & 41.1 & 100.0 \\
\hline
\end{tabular}

\footnotetext{
Source (Researcher, 2018)

Table 12 shows that $119(36.5 \%)$ of the respondents strongly agreed with the statement that the tax cut enhanced saving and asset allocation decisions, 108(33.1\%) agreed, 43(13.2\%) of the respondents were undecided, $32(9.8 \%)$ strongly disagreed and $24(7.4 \%)$ of the respondents disagreed with the statement. The study findings suggested that most $227(69.6 \%)$ of the people living in the rural areas opined that the tax cut enhanced saving and asset allocation decisions. This implies that tax cut will enhance saving and asset allocation decisions among low income household in the rural areas. This supports the finding of Kodom (2013) that in this case an increase in the taxes would not only prevent household savings but it might also lead to negative personal savings if some income-earners were induced to disinvest accumulated wealth in order to counterbalance the reduction in income (actual or in purchasing power) allocated to current consumption expenditure

Similarly, $120(36.8 \%)$ of the respondents strongly agreed with the statement that increased government spending enhanced saving and asset allocation decisions, 110(33.7\%) agreed, 44(13.5\%) disagreed, 30(9.2\%) of the
} 
respondents were undecided and $22(6.7 \%)$ of the respondents strongly agreed with the statement. It emerged from the study that most $230(70.5 \%)$ of the people living in the rural areas indicated that increased government spending enhanced saving and asset allocation decisions.

Additionally, 163(50.0\%) of the respondents strongly agreed with the statement that regulation of inflation by the government enhanced saving and asset allocation decisions, 103(31.6\%) agreed, 44(13.5\%) of the respondents were undecided, $13(4.0 \%)$ disagreed and $3(0.9 \%)$ of the respondents were in a strong disagreement with the statement. The study findings suggested that majority $266(81.6 \%)$ of the people living in rural areas believed that regulation of inflation by the government enhanced saving and asset allocation decisions.

Lastly, $149(45.7 \%)$ of the respondents agreed with the statement that adjustment of interest rates by the government enhanced saving and asset allocation decisions, 134(41.1\%) strongly agreed, 27(8.3\%) disagreed, $9(2.8 \%)$ of the respondents were undecided and $7(2.1 \%)$ of the respondents strongly disagreed with the statement. It emerged from the study that most $283(86.8 \%)$ of the people living in the rural areas opined that adjustment of interest rates by the government enhanced saving and asset allocation decisions. This implies that adjustment of interest rates by the government enhances saving and asset allocation decisions. This supports the findings of Kodom (2013) believes that the amount to be gained by the interest rate, even if it is high, normally has little economic significance to savers, who deposit or invest amounts in a small average volume.

\subsection{Relationship between household head's demographic information and saving and asset allocation behaviours}

The study established if there was a relationship between household head's demographic information and saving and asset allocation in rural Kenya: A case of Oyani Sub Location, Kenya. The analysis, therefore, opens with the descriptive statistics household head's demographic information (frequency and percentage) for the level of agreement on a five point Likert scale of the household head's demographic (Table 13). Where; 1=strongly disagree, 2=Disagree, 3=Undecided, 4= Agree and 5= Strongly Agree.

Table 13: Household head's demographic information and savings and asset allocation behaviour

\begin{tabular}{|c|c|c|c|c|c|c|c|}
\hline $\begin{array}{l}\text { Statement on household head's demographic } \\
\text { information }\end{array}$ & & SD & D & $\mathbf{U}$ & $\mathbf{A}$ & SA & Total \\
\hline \multirow{2}{*}{$\begin{array}{l}\text { Gender difference in savings and asset allocation } \\
\text { exists among people in the rural areas }\end{array}$} & $\mathrm{F}$ & 47 & 22 & 19 & 139 & 99 & 326 \\
\hline & $\%$ & 14.4 & 6.7 & 5.8 & 42.6 & 30.4 & 100.0 \\
\hline \multirow{2}{*}{$\begin{array}{l}\text { The higher the age the more the saving and asset } \\
\text { allocation will be among people in the rural areas }\end{array}$} & $\mathrm{F}$ & 19 & 37 & 22 & 135 & 113 & 326 \\
\hline & $\%$ & 5.8 & 11.3 & 6.7 & 41.4 & 34.7 & 100.0 \\
\hline \multirow{2}{*}{$\begin{array}{l}\text { The education level for the household's head } \\
\text { determines the saving and asset allocation among } \\
\text { people in the rural areas }\end{array}$} & $\mathrm{F}$ & 7 & 12 & 48 & 90 & 169 & 326 \\
\hline & $\%$ & 2.1 & 3.7 & 14.7 & 27.7 & 51.8 & 100.0 \\
\hline \multirow{2}{*}{$\begin{array}{l}\text { The occupation for the household's head } \\
\text { determines the saving and asset allocation among } \\
\text { people in the rural areas }\end{array}$} & $\mathrm{F}$ & 10 & 30 & 9 & 148 & 129 & 326 \\
\hline & $\%$ & 3.1 & 9.2 & 2.8 & 45.4 & 39.6 & 100.0 \\
\hline
\end{tabular}

\section{Source (Researcher, 2018)}

Table 13 shows that $139(42.6 \%)$ of the respondents agreed with the statement that gender difference in savings and asset allocation existed among people in the rural areas, 99(30.4\%) strongly agreed, 47(14.4\%) strongly disagreed, 22(6.7\%) disagreed and $19(5.8 \%)$ of the respondents were undecided on the statement. The study findings suggested that most $238(73.0 \%)$ of the people living in the rural areas opined that the gender difference in savings and asset allocation existed among people in the rural areas. This supports the finding of Denizer et al. (2000) that that households headed by women exhibit significantly higher savings rates than those of men. . Dupas and Robinson (2013) adds that women have the capacity to save in spite of being faced with a number of barriers.

Similarly, $135(41.4 \%)$ of the respondents agreed with the statement that the higher the age the more the saving and asset allocation was among people in the rural areas, 113(34.7\%) strongly agreed, 37(11.3\%) disagreed, $22(6.7 \%)$ of the respondents were undecided and $19(5.8 \%)$ of the respondents strongly agreed with the statement. It emerged from the study that most $248(76.1 \%)$ of the people living in the rural areas indicated that higher the age the more the saving and asset allocation was among people in the rural areas. This implies that higher older people have highest chances of saving and asset allocation was among people in the rural areas. 
This concurs with the findings of Quartey and Blankson (2008). that saving rates for households with heads aged 41-50, 51-60, and aged 61 or above were higher than those with heads aged 30 or below. Chakrabarty et al (2008) also believed that savings of the households with heads over the age of 61 could be higher due to generous tax benefits of superannuation contributions. Additionally, 169(51.8\%) of the respondents strongly agreed with the statement that the education level for the household's head determined the saving and asset allocation among people in the rural areas, 90(27.7\%) agreed, 48(14.7\%) of the respondents were undecided, $12(3.7 \%)$ disagreed and $7(2.1 \%)$ of the respondents were in a strong disagreement with the statement. The study findings suggested that majority $259(79.5 \%)$ of the people living in rural areas believed that the education level for the household's head determined the saving and asset allocation among people in the rural areas. This implies that those who have higher level of education can easily save compared ot those who have low education. This is in line with the findings of Carpenter and Jensen (2002) that education level for the household's head determined the saving and asset allocation among people in the rural areas. Lastly, 148(45.4\%) of the respondents agreed with the statement that the occupation for the household's head determined the saving and asset allocation among people in the rural areas, $129(39.6 \%)$ strongly agreed, 30(9.2\%) disagreed, 10(3.1\%) strongly disagreed and $9(2.8 \%)$ of the respondents were undecided on the statement. It emerged from the study that most $277(85.0 \%)$ of the people living in the rural areas opined that the occupation for the household's head determined the saving and asset allocation among people in the rural areas. This supports the findings of Issahaku (2011) that the amount of income one makes mostly depend on his or her occupation and as such, it has postulated that people whose occupation earn them higher incomes are able to have higher savings than those who are into menial jobs.

4.5 Inferential statistics analysis of savings and asset allocation behaviour among low income individuals in rural areas

To test the hypotheses, the study adopted multiple linear regression as the most appropriate statistical techniques. The study, thus, opens with the test for assumption of the for multiple linear regression analysis.

4.5.1 Assumptions for multiple regression analysis

The following assumptions for adoption of multiple regression analysis were tested; linearity assumption and multicollinearity.

\subsubsection{Assumption of linearity}

Pearson's product moment correlation coefficients were used to test linearity assumption. The purpose of using correlation was to identify the determinants that provide best predictions for conducting regression analysis. The inter-correlations among the variables are shown in Table 14.

Table 14: Test for linearity

\begin{tabular}{|c|c|c|c|c|c|c|}
\hline \multicolumn{7}{|c|}{ Correlations } \\
\hline & & $\begin{array}{c}\text { Saving and asset } \\
\text { allocation } \\
\text { behaviour }\end{array}$ & $\begin{array}{c}\text { Financial } \\
\text { literacy }\end{array}$ & $\begin{array}{l}\text { Financial institution } \\
\text { characteristics }\end{array}$ & $\begin{array}{l}\text { Fiscal } \\
\text { policy }\end{array}$ & $\begin{array}{c}\text { Household head's } \\
\text { demographic } \\
\text { information }\end{array}$ \\
\hline \multirow{3}{*}{$\begin{array}{l}\text { Saving and asset } \\
\text { allocation behaviour }\end{array}$} & $\begin{array}{l}\text { Pearson } \\
\text { Correlation }\end{array}$ & 1 & & & & \\
\hline & Sig. (2-tailed) & & & & & \\
\hline & $\mathrm{N}$ & 326 & & & & \\
\hline \multirow{3}{*}{ Financial literacy } & $\begin{array}{l}\text { Pearson } \\
\text { Correlation }\end{array}$ & $.787^{* *}$ & 1 & & & \\
\hline & Sig. (2-tailed) & .000 & & & & \\
\hline & $\mathrm{N}$ & 326 & 326 & & & \\
\hline \multirow{3}{*}{$\begin{array}{l}\text { Financial institution } \\
\text { characteristics }\end{array}$} & $\begin{array}{l}\text { Pearson } \\
\text { Correlation }\end{array}$ & $.869^{* *}$ & $.726^{* *}$ & 1 & & \\
\hline & Sig. (2-tailed) & .000 & .000 & & & \\
\hline & $\mathrm{N}$ & 326 & 326 & 326 & & \\
\hline \multirow{3}{*}{ Fiscal policy } & $\begin{array}{l}\text { Pearson } \\
\text { Correlation }\end{array}$ & $.854^{* *}$ & $.742^{* *}$ & $.856^{* *}$ & 1 & \\
\hline & Sig. (2-tailed) & .000 & .000 & .000 & & \\
\hline & $\mathrm{N}$ & 326 & 326 & 326 & 326 & \\
\hline \multirow{3}{*}{$\begin{array}{l}\text { Household head's } \\
\text { demographic information }\end{array}$} & $\begin{array}{l}\text { Pearson } \\
\text { Correlation }\end{array}$ & $.898^{* *}$ & $.794^{* *}$ & $.867^{* *}$ & $.876^{* *}$ & 1 \\
\hline & Sig. (2-tailed) & .000 & .000 & .000 & .000 & \\
\hline & $\mathrm{N}$ & 326 & 326 & 326 & 326 & 326 \\
\hline
\end{tabular}

**. Correlation is significant at the 0.01 level (2-tailed).

Source (Researcher, 2018) 
As shown in Table 14, there is a correlations between financial literacy and saving and asset allocation behaviour $\left(r=.787^{* *}\right)$, financial institutions' characteristics and saving and asset allocation behaviour $\left(r=.869^{* *}\right)$, fiscal policy and saving and asset allocation behaviour $\left(r=.854^{* *}\right)$ and household's head's demographic information and saving and asset allocation behaviour $\left(r=.898^{* *}\right)$. This implies that the linearity assumption was therefore, satisfied. After the assumptions, the study established the factors that influence saving behaviours and asset allocation among low income households in rural areas Kenya: A case of Oyani Sub Location, Kenya.

4.5.2 Saving behaviours and asset allocation among low income households in rural areas Multiple linear regression analysis was used to test the formulated hypotheses. First, the model summary was analyzed to establish the strength of the conceptualized financial literacy, financial institutions' characteristics, fiscal policy and household's head's demographic information in predicting saving behaviours and asset allocation.

Table 15: Model Summary

Model Summary

\begin{tabular}{lccccc}
\hline Model & $\mathrm{R}$ & R Square & $\begin{array}{c}\text { Adjusted R } \\
\text { Square }\end{array}$ & $\begin{array}{c}\text { Std. Error of the } \\
\text { Estimate }\end{array}$ & Durbin-Watson \\
\hline 1 & $.924^{\mathrm{a}}$ & .853 & .852 & .27569 & 1.915 \\
\hline
\end{tabular}

a. Predictors: (Constant), financial literacy, financial institutions' characteristics, fiscal policy and household's head's demographic information

b. Dependent Variable: Savings behaviour and asset allocation decision

Source (Researcher, 2018)

Results presented in Table 15 reveal that the financial literacy, financial institutions' characteristics, fiscal policy and household's head's demographic information explains $85.2 \%$ of the variation in savings and asset allocation behaviour (Adjusted R Square = 0.852). Therefore, the remaining $14.8 \%$ is explained by other factors not considered in the study. Second, the ANOVA output was examined to check whether the proposed model was viable.

Table 16: Analysis of Variance (ANOVA)

ANOVAa

\begin{tabular}{llccccc}
\hline Model & & Sum of Squares & df & Mean Square & F & Sig. \\
\hline \multirow{2}{*}{1} & Regression & 142.112 & 4 & 35.528 & 467.459 & $.000^{\mathrm{b}}$ \\
& Residual & 24.397 & 321 & .076 & & \\
& Total & 166.509 & 325 & & &
\end{tabular}

a. Dependent Variable: Savings behaviour and asset allocation decision

b. Predictors: (Constant), financial literacy, financial institutions' characteristics, fiscal policy and household's head's demographic information

Source (Researcher, 2018)

Results shown in Table 17 reveal that the F-statistic was highly significant $(F=467.459 \mathrm{p}<0.05)$, this shows that the model was valid. 
Coefficients $^{a}$

\begin{tabular}{|c|c|c|c|c|c|c|c|}
\hline \multirow[t]{2}{*}{ Model } & \multicolumn{2}{|c|}{$\begin{array}{l}\text { Unstandardized } \\
\text { Coefficients }\end{array}$} & \multirow{2}{*}{$\begin{array}{c}\begin{array}{c}\text { Standardized } \\
\text { Coefficients }\end{array} \\
\text { Beta }\end{array}$} & \multirow[t]{2}{*}{$\mathrm{t}$} & \multirow[t]{2}{*}{ Sig. } & \multicolumn{2}{|c|}{$\begin{array}{l}\text { Collinearity } \\
\text { Statistics }\end{array}$} \\
\hline & B & Std. Error & & & & Tolerance & VIF \\
\hline (Constant) & .395 & .098 & & 4.034 & .000 & & \\
\hline Financial literacy & .158 & .037 & .153 & 4.277 & .000 & .359 & 2.789 \\
\hline $\begin{array}{l}\text { Financial institutions' } \\
\text { characteristics }\end{array}$ & .282 & .046 & .288 & 6.130 & .000 & .207 & 4.823 \\
\hline Fiscal policy & .125 & .044 & .139 & 2.854 & .005 & .193 & 5.187 \\
\hline $\begin{array}{l}\text { Household's head's } \\
\text { demographic information }\end{array}$ & .358 & .048 & .406 & 7.489 & .000 & .155 & 6.441 \\
\hline
\end{tabular}

\section{a. Dependent Variable: Saving behaviour and asset allocation decision}

\section{Source (Researcher, 2018)}

Results of the regression coefficients presented in Table 4.14 shows that the estimates of $\beta$ values and give an individual contribution of each predictor to the model. The $\beta$ value tells us about the relationship between savings and asset allocation decision with each predictor. The $\beta$ value for financial literacy (.153), financial institutions' characteristics (.288), fiscal policy (.139) and household's head's demographic information (.406) were positive. Therefore, from the results the model was then specified as:-

$y=\beta_{1} x_{1}+\beta_{2} x_{2}+\beta_{3} x_{3}+\beta_{4} x_{4}+\varepsilon \ldots$

Savings behaviour and asset allocation decision= .153 financial literacy +.288 financial institutions' characteristics +.139 fiscal policy +.406 household's head's demographic information

The coefficients for each of the variables indicates the amount of change one could expect in Savings behaviour and asset allocation decision given a one-unit change in the value of that variable, given that all the variables in the model are standardized basing on the standardized coefficients. Results reveal standardized regression coefficient for financial literacy $(\beta 1=0.153)$, implies that an increase of 1 standard deviation in financial literacy is likely to result in a 0.153 standard deviations increase in savings behaviour and asset allocation decision.

Moreover, standardized regression coefficient for financial institutions' characteristics $(\beta 1=0.288)$, implies that an increase of 1 standard deviation in financial institutions' characteristics is likely to result in a 0.288 standard deviations increase in savings behaviour and asset allocation decision. Likewise, standardized regression coefficient for fiscal policy $(\beta 1=0.139)$, implies that an increase of 1 standard deviation in fiscal policy is likely to result in a 0.139 standard deviations increase in savings behaviour and asset allocation decision. Lastly, standardized regression coefficient for household's head's demographic information $(\beta 1=0.406)$, implies that an increase of 1 standard deviation in household's head's demographic information is likely to result in a 0.406 standard deviations increase in savings behaviour and asset allocation decision.

T-test was used to identify whether the predictors were making a significant contribution to the model. When the t-test associated with $\beta$ value is significant then the predictor is making a significant contribution to the model. The smaller the value of significance (the larger the value of $t$ ) meaning greater is the contributor of that predictor. The results show that financial literacy $(\mathrm{t}=4.277, \mathrm{P}<.05)$, financial institutions' characteristics $(\mathrm{t}$ $=6.130, \mathrm{P}<.05)$, fiscal policy $(\mathrm{t}=2.854, \mathrm{P}<.05)$ and household head's demographic information $(\mathrm{t}=7.489, \mathrm{P}<.05)$. These findings indicated that financial literacy, financial institutions' characteristics, fiscal policy and household's head's demographic information as predictors, which significantly affect savings behaviour and asset allocation decision.

These results imply that household head's demographic information is most $(\mathrm{t}=7.489, \mathrm{P}<.05)$ important predictor for savings behaviour and asset allocation decision. Lastly, collinearity, tests were carried out using tolerance and Variance Inflation Factor (VIF) statistics. For this model, VIF values are all below 10 and tolerance statistics are all well above 0.1 and we can conclude that there is no Collinearity within our data. 


\subsection{SUMMARY, CONCLUSION AND RECOMMENDATIONS}

\subsection{Summary of the findings}

\subsubsection{Relationship between financial literacy and saving and asset allocation decisions}

On the relationship between financial literacy and saving and asset allocation decision, the study findings suggested that most $250(76.7 \%)$ of the people living in the rural areas opined that understanding on how financial institutions work improved saving and asset allocation decisions. Similarly, it emerged from the study that most 254(77.9\%) of the people living in the rural areas indicated that being knowledgeable in the areas of saving, spending and budgeting increased saving and asset allocation decisions. Additionally, the study findings suggested that majority $256(78.5 \%)$ of the people living in the rural areas believed that knowledge on how to handle financial affairs and how to be responsible financially increased saving and asset allocation decisions. Lastly, it emerged from the study that most 265(81.3\%) of the people living in the rural areas opined that ability to make informed judgments and effective decisions regarding the use and management of money enhanced saving and asset allocation decisions. The inferential statistics results revealed a standardized regression coefficient for financial literacy $(\beta 1=0.153)$ which implies that an increase of 1 standard deviation in financial literacy is likely to result in a 0.153 standard deviations increase in savings behaviour and asset allocation decision.

\subsubsection{How financial institution's characteristics influence saving and asset allocation decision}

The study findings suggested that most 247(75.8\%) of the people living in the rural areas opined that the financial institution accessibility/location enhanced saving and asset allocation decisions. Similarly, it emerged from the study that most $259(79.4 \%)$ of the people living in the rural areas indicated that the interest rate charged by the financial institution determined saving and asset allocation decisions. Additionally, the study findings suggested that majority $280(85.9 \%)$ of the people living in rural areas believed that the financial institution credit availability enhanced saving and asset allocation decisions. Lastly, it emerged from the study that most $272(83.5 \%)$ of the people living in the rural areas opined that the financial institution minimum deposit requirements determined saving and asset allocation decisions. The inferential statistics results revealed a standardized regression coefficient for financial institutions' characteristics $(\beta 1=0.288)$ which implies that an increase of 1 standard deviation in financial institutions' characteristics is likely to result in a 0.288 standard deviations increase in savings behaviour and asset allocation decision.

\subsubsection{How fiscal policy influence saving and asset allocation decisions}

The study findings suggested that most $227(69.6 \%$ ) of the people living in the rural areas opined that the tax cut enhanced saving and asset allocation decisions. Similarly, it emerged from the study that most 230(70.5\%) of the people living in the rural areas indicated that increased government spending enhanced saving and asset allocation decisions. Additionally, the study findings suggested that majority 266(81.6\%) of the people living in rural areas believed that regulation of inflation by the government enhanced saving and asset allocation decisions. Lastly, it emerged from the study that most 283(86.8\%) of the people living in the rural areas opined that adjustment of interest rates by the government enhanced saving and asset allocation decisions. The inferential statistics results revealed a standardized regression coefficient for fiscal policy $(\beta 1=0.139)$ which implies that an increase of 1 standard deviation in fiscal policy is likely to result in a 0.139 standard deviations increase in savings behaviour and asset allocation decision.

\subsubsection{Relationship between household head's demographic information and saving and asset allocation} decisions

On the relationship between household head's demographic information and savings and asset allocation decisions, the study findings suggested that most $238(73.0 \%)$ of the people living in the rural areas opined that the gender difference in savings and asset allocation existed among people in the rural areas. Similarly, it emerged from the study that most $248(76.1 \%)$ of the people living in the rural areas indicated that higher the age the more the saving and asset allocation was among people in the rural areas. Additionally, the study findings suggested that majority $259(79.5 \%)$ of the people living in rural areas believed that the education level for the household's head determined the saving and asset allocation among people in the rural areas. Lastly, it emerged from the study that most $277(85.0 \%)$ of the people living in the rural areas opined that the occupation for the household's head determined the saving and asset allocation among people in the rural areas. The inferential statistics results revealed a standardized regression coefficient for household's head's demographic information $(\beta 1=0.406)$ which implies that an increase of 1 standard deviation in household's head's demographic information is likely to result in a 0.406 standard deviations increase in savings behaviour and asset allocation decision. 


\subsection{Conclusion}

In regard to the literature review, findings and discussions, the study concluded that financial literacy, financial institutions' characteristics, fiscal policy and household's head's demographic information significantly influence the savings behaviour and asset allocation decision among low income households in rural areas Kenya: A case of Oyani Sub Location, Kenya. Therefore, factors such as financial literacy, financial institutions' characteristics, fiscal policy and household's head's demographic information are vital in the increase of savings and asset allocations. Moreover, household's head's demographic information remains the most important predictor of the savings behaviour and asset allocations decisions.

On the relationship between financial literacy and saving and asset allocation decision, the study concluded that, financial literacy significantly influence savings behaviour and asset allocations decisions. That is understanding on how financial institutions work; being knowledgeable in the areas of saving; knowledge on how to handle financial affairs and how to be responsible financially; ability to make informed judgments and effective decisions regarding the use and management of money enhances chances of saving and asset allocation. Therefore, financial literacy plays a positive role on savings behaviour and asset allocations decisions.

On the influence of financial institutions' characteristic on saving and asset allocation decision the study concluded that, financial institutions' characteristic significantly influence savings behaviour and asset allocations decisions. That is low income households in rural areas consider the financial institution accessibility/location, interest rate charged, credit availability and financial institution minimum deposit requirements for saving and asset allocation decision.

Moreover, the study concluded that, fiscal policy significantly influence savings behaviour and asset allocations decisions. That is tax cut, increased government spending, regulation of inflation by the government and adjustment of interest rates by the government is likely increase the chances of low income households in the rural areas to improve on savings and asset allocation decision. Lastly, the study concluded that, household head's demographic information significantly influence savings behaviour and asset allocations decisions. That is the financial institutions consider the gender, age, education level and the occupation for the household's head when saving and making decision on asset allocation.

\subsection{Policy Recommendations}

The findings of the study suggested that due to the importance of financial literacy, financial institutions' characteristics, fiscal policy and household's head's demographic information in determining the savings behaviour and asset allocation decision among low income households in rural areas Kenya, the government and other stakeholder to focus more on the issue of savings and asset allocation decisions for low income households in rural areas. In particular, they should train low income households in rural areas to have financial knowledge. More efforts are needed from the regulatory agencies and government in general toward helping low income households in rural areas grow and make decisions as their growth will be good for the wider economy.

\subsection{Recommendation for further studies}

Further study should be narrowed down to the effect of each (financial literacy, financial institutions' characteristics, fiscal policy and household's head's demographic information) on saving behaviour and asset allocation decision.

A pre-test posttest study should be carried on sampled low income households in rural areas to determine the effect of financial literacy, financial institutions' characteristics, fiscal policy and household's head's demographic information on saving behaviour and asset allocation decision.

\section{REFERENCES}

Aflonia Nyambura Mbuthia (2011) Households' Saving Decisions In Kenya Ph.D Thesis Kenyatta University

Aryeetey, E. and Udry, C. (2000). Savings in Sub-Saharan Africa. Center for International Development, Working Paper No. 38.

Ando, A., \& Modigliani, F. (1963). The Life-Cycle Hypothesis of Saving: Aggregate Implications and Tests. American Economic Review, 53(1), 5584.

Bendig, M., Giesbert, L., and Steiner, S. (2009). Savings, Credit, and Insurance: Household Demand for Formal Financial Services in Rural Ghana. Brookings Working Paper Institute, 76.

Birhanu Melesse (2015) Factors Affecting Rural Households Savings: The Case Of Gedeb Hasasa District, West Arsi Zone, Oromia Regional State, Ethiopia Master's Thesis Haramaya University, Haramaya 
Beal, D.J., Delpachtra S.B.,(2003) Financial Literacy and Family and Consumer Sciences: Journal of Family and Consumer Sciences. Vol 94, No1, pp 15-28.

Brown S. and Taylor, K. (2006). Financial Expectations, Consumption and Saving: A Microeconomic Analysis. Fiscal Studies, Vol. 27, no. 3, pp. 313-338

Boring, I. (2010). An Empirical Analysis of Household Savings Behavior in Uganda. Andrew Young School of Policy Studies, Georgia State University.

Carpenter, S., and Jensen, R. (2002). Household Participation in Formal and Informal Savings Mechanisms: Evidence from Pakistan, Review of Development Economics, 6(3), 314-328.

Chandararot, K., and Dannet, L. (2007). National Survey on Saving Needs and Opportunities for Poor Households in Cambodia: Developing Deposit Services in Rural and Urban Cambodia. Cambodia Institute of Development Study.

Chen, H. Volpo. R.P. (1998) An Analysis of Personal Financial Literacy among College Students. Financial Services Review. Vol7, No2. Pp 107-128.

Deshpande, R. (2006). Safe and Accessible: Bringing Poor Savers into the Formal Financial System. Focus Note 37. CGAP: Washington, D.C.

Dirschmid, W and Glatzer, E (2004). Determinants of the Household Saving Rate in Austria. Monetary Policy and the Economy, 4, 25-38.

Dupas, P. and Robinson, J. (2013). Why Don't the Poor Save More? Evidence from Health Savings Experiments. American Economic Review, American Economic Association, vol. 103(4), pages 1138-71

Dupas, P. and Robinson, J. (2009). Savings Constraints and Microenterprise Development: Evidence from a Field Experiment in Kenya. National Bureau of Economic Research; NBER Working Paper Series: Working Paper 14693

Dusenberry, J. S. (1949). Income, Saving and the Theory of Consumer Behaviours. Cambridge: Harvard University Press

Economy Watch. (2010). Gross National Savings (percent of GDP) data for all countries. www.economywatch.com. Accessed on 05/09/2016.

Falahati Leila and Paim Laily (2012), "Gender Differences in Saving Behavior Determinants among University Students", Journal of Basic and Applied Scientific Research, www.textroad.com.

Fisher, P.J. (2010). Gender differences in personal saving behaviors. Journal of Financial Counselling and Planning Education, 21(1), pp. 14-24.

Friedman, M. (1957). A Theory of the Consumption Function. Princeton, NJ: Princeton University Press for the National Bureau of Economic Research.

Hassan, A.F.M., Salim, R. and Bloch, H. (2011). Population age structure, saving, capital flows and the real exchange rate: a survey of the literature. Journal of Economic Surveys Vol. 25, No. 4, pp. 708736

Hospes O., Musinga, M., and Ongeayo, M. (2002). An Evaluation of Micro-Finance Programmes in Kenya as Supported through the Dutch Co-Financing Programme: With a focus on KWFT. Study commissioned by Steering Committee for the Evaluation of the Netherlands Co-financing Programme.

Hoos Karin (2010), "Saving Behavior in Cebu City: Contribution to the Livelihoods of Urban Poor Households", Master Thesis, International Development Studies.

Issahaku Haruna (2011), "Determinants of Saving and Investment in Deprived District Capitals in Ghana -A Case Study of Nadowli in the Upper West Region of Ghana”, Wilolud Journals, Continental J. Social Sciences 4 (1): 1 - 12, 2011. 
Kibet Lawrence, Mutai Benjamin, Ouma Desterio, Ouma Shem and Owuor George (2009), "Determinants of Household Saving: Case Study of Smallholder Farmers, Entrepreneurs and Teachers in Rural Areas 0f Kenya", Journal of Development and Agricultural Economics, Vol. 1(7).

Keynes, J. (1936). The General Theory of Employment, Interest and Money. New York: Harcourt, Brace \& Co.

Kiiza, B., and Pederson, G. (2002). Household Financial Savings Mobilization: Empirical Evidence from Uganda. Journal of African Economies 10(4), 390-409.

Kodom Michael 2013 Savings Habit And Use Of Savings Among Households In Ga-East Municipality Masters Thesis University Of Ghana

Lusardi, A., Mitchell, O.S. (2007)., Financial Literacy and Planning: Implications for retirement Preparedness Evidence and Implications for Financial Education. Journal of Business Economics Vol 42, No1, pp 35-44.

Lusardi, A. (1998). On the importance of the precautionary saving motive. American Economic Review, Papers and Proceedings, vol. 88, pp. 449-53.

Mas, I. (2009). Reframing Micro-finance: Enabling Small Savings and Payments Everywhere. Financing for Development. Paper Presented in the Commonwealth Heads of Governments Meeting, Trinidad and Tobago, 27-29 November, 2009.

Masson Paul, Bayoumi Tamim, and Samiei Hossein, (2005), "International Evidence on the Determinants of Private Saving", The World Bank Economic Review, Vol. 12, No. 3: 483-501.

Mohan, R. (2006). Causal Relationship between Savings and Economic Growth in Countries with Different Income Levels. Economics Bulletin, 5(3) 1-12

Modigliani, F. and Ando, A.K. (1957). Tests of the Life Cycle Hypothesis of Savings: Comments and Suggestions. Bulletin of the Oxford University Institute of Economics \& Statistics, Volume 19, Issue 2, pages 99-124

Modigliani, F., \& Brumberg, R. (1954). Utility analysis and the consumption function: an interpretation of crosssection data in Post-Keynesian Economics. K. Kurihara Publishing House, New Brunswick, NJ: Rutgers University Press.

Mwanza Joseph F.(2011) Assessment Of Factors Of Household Capital/Assets That Influence Income Of Smallholder Farmers Under International Development Enterprises (IDE) In Zambia Masters Thesis Ghent University, Belgium

Niculescu-Aron, I. and Mihăescu, C. (2012). Determinants of Household Savings in EU: What Policies for Increasing Savings?. Procedia - Social and Behavioral Sciences 58 (2012) 483 - 492

Newman, C., Tarp, F., Broek, K., Quang, C., and Khai, L. (2007). Household Savings in Vietnam: Insights from a 2006 Rural Household Survey.

Nga Marie (2007), “An Investigative Analysis into the Saving Behaviour of Poor Households in Developing Countries: With Specific Reference to South Africa", Research Report prepared in partial fulfillment of the requirement for the degree of Masters in Economics

N.S. Mahdzan, S. Tabiani(2013) The Impact of Financial Literacy on Individual Saving: an Exploratory Study in Malaysian Context. Journal of Transformation in Business \& Economics Vol12, No1(28) PP41-55.

Odhiambo, M. N. (2008). Financial depth, savings and economic growth in Kenya: A dynamic causal linkage. Economic Modelling 25, 704-713

Rehman Hafeez, Faridi Muhammad and Bashir Furrukh (2010), "Households Saving Behaviour in Pakistan: A Case of Multan District", Pakistan Journal of Social Sciences (PJSS), Vol. 30, No. 1 (September 2010), pp. 17-29.

Republic of Kenya. (2001). Economic Survey. Nairobi: Government Printer.

Republic of Kenya. (2002). National Development Plan. Nairobi: Government printer 
Republic of Kenya. (2007). Vision 2030 Strategy for National Transformation: Accelerating Equitable Economic and Social Development for a Prosperous Kenya. Ministry of Planning and National Development. Nairobi: Government Printer.

Republic of Kenya. (2007). Statistical Abstract. Nairobi: Government Printer.

Republic of Kenya. (2009). Central Bank of Kenya Monthly Economic Review. Nairobi: Government Printer.

Republic of Kenya. (2010). Economic Survey. Nairobi: Government Printer.

Rogg, C. (2000). The Impact of Access to Credit on the Saving behavior of Micro-entrepreneurs: Evidence from Three Latin American Countries. A paper based on a Thesis submitted to the University of Oxford in June 1999.

Turner Kea and Manturuk Kim (2012), "Individual, Institutional, and Structural Determinants of Household Savings Decisions", Utrecht University, Working Paper: April 2012.

Todaro, P. M. and Smith, S. C. (2006). Economic Development (9th Ed.). Pearson Education Limited, England.

Subhashree Nayak 2013 Determinants and Pattern of Saving Behaviour in Rural Households of Western Odisha Masters Thesis Department of Humanities and Social Sciences National Institute of Technology Rourkela - 769008, India

Serieux, J. (2009). Aid and Savings in Sub-Saharan Africa: Should We Worry about Rising Aid Levels. International Policy Centre for Inclusive Growth. Working paper. No.50.

Gina A. N. Chowa, Rainier D. Masa, David Ansong(2012) Determinants of Saving among Low-Income Individuals in Rural Uganda: Evidence from Assets Africa Journal of Advances in Applied Sociology 2012. Vol.2, No.4, 280-291

Sukhdeve, M. (2008). Savings of the Poor: Prospects for Financial Inclusion, Cab Calling, January-March, 2008

United Nations Conference on Trade and Development. (2007). Economic Development in Africa: Reclaiming Policy Space Domestic Resource Mobilization and Developmental States. United Nations: New York.

Rehman, H., Bashir, F., \& Faridi, M. Z. (2011). Saving behavior among different income groups in Pakistan: A micro study. International Journal of Humanities and Social Science, 1, 268-277.

Wangwe, S., and Charle, P. (2004). Innovative Approaches to Domestic Resource Mobilization in Selected LDCs. CDP Background Paper, 6. 